\title{
Pengaruh Pemanfaatan Buku KIA dalam Pengkajian ROT dan MAP terhadap Deteksi Dini Pre Eklamsia di Polindes
}

\author{
Kolifaha $^{\text {a }}$ Erika Agung Mulyaningsiha

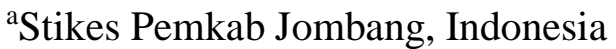 \\ Email korespondensi: kolifah0607@yahoo.com
}

\begin{abstract}
Introduction: One way to detect the presence of eclampsia is to do early detection using ROT and MAP. Efforts to prevent the occurrence of preeclampsia are routine antenatal surveillance which one of them is to test the possibility of preeclampsia with conventional examinations namely blood pressure along with urine protein, ROT and MAP examination. The purpose of this research is to determine the effect of the use of KIA book in the ROT and MAP assessment of pre eclampsia early detection in Dukuh Arum Megaluh Jombang. Method: This study used Cross-sectional design, that observations of independent variables and dependent variables were carried out at the same time. The population in this study were 87 third trimester pregnant women who had KIA book and conducted ANC examinations in September and October at the Puskesmas Jelak Ombo Jombang. Results: Chi Square test results showed that there was a significant influence $p<0.05$ between the results of ROT examination with the incidence of pre-eclampsia, and there was a significant effect of $p<0.05$ between the results of the MAP examination with the incidence of pre-eclampsia. Examination of ROT and MAP is documented in KIA book. KIA book is very effective in utilizing pre-eclampsia early detection through ROT and MAP measurements. Conclusion: KIA book is a very important book for pregnant women, because in the KIA book the condition of the mother during pregnancy is recorded thus information about pregnant women is obtained from one of the results of the ROT and MAP examination. It can be used in early detection before pre-eclampsia for pregnant women's body weight.
\end{abstract}

Keywords: Early detection, pre-eclampsia, KIA book, MAP, ROT

\begin{abstract}
Abstrak
Pendahuluan: Salah satu cara untuk mendeteksi adanya eklamsia adalah dengan melakukan deteksi dini menggunakan ROT dan MAP. Usaha untuk mecegah terjadinya preeklamsia yaitu dengan pengawasan antenatal yang rutin dimana salah satunya adalah dengan dilakukan uji kemungkinan preeklamsia dengan pemeriksaan konvensional yaitu tekanan darah beserta protein urine dan pemeriksaan ROT dan MAP. Tujuan penelitian ini adalah untuk mengetahui pengaruh pemanfaatan buku KIA dalam pengkajian ROT dan MAP terhadap deteksi dini Pre Eklamsia Di Polindes Dukuh Arum Megaluh Jombang. Metode: Desain penelitian ini menggunakan rancangan Cross sectional, dimana pengamatan variable bebas (independent) dan variable terikat (dependent) dilakukan dalam satu waktu secara bersamaan Populasi dalam penelitian ini ibu hamil TM III yang memiliki buku KIA dan melakukan pemeriksaan ANC pada bulan september dan oktober di Puskesmas Jelak Ombo Jombang yaitu sejumlah 87 responden. Hasil: Hasil uji Chi Square menunjukkan bahwa ada pengaruh yang significan $\mathrm{p}<0,05$ antara hasil pemeriksaan ROT dengan kejadian pre eklamsia, ada pengaruh yang significant $\mathrm{p}<0,05$ antara hasil pemeriksaan MAP dengan kejadian pre eklamsia. Pemeriksaan ROT dan MAP di dokumentasikan dalam buku KIA. Buku KIA sangat efektif dalam pemanfaatan
\end{abstract} Kolifah, dkk., Pengaruh Pemanfaatan Buku KIA 


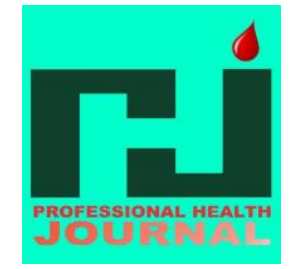

\section{PROFESIONAL HEALTH JOURNAL}

Volume 1, No. 2, Juni 2020 (Hal. 73-83)

Available Online at https:// https://www.ojsstikesbanyuwangi.com

deteksi dini pre eklamsia melalui pengukuran ROT dan MAP. Kesimpulan: Buku KIA merupakan buku yang sangat penting bagi ibu hamil, karena di dalam buku KIA terekam kondisi ibu selama hamil sehingga didapatkan informasi tentang keadaan kehamilan ibu hamil salah satunya hasil pemeriksaan ROT dan MAP, sehingga dapat di lakukan deteksi dini terjadinya pre eklamsia melalui tekanan darah dan berat badan ibu hamil.

Kata kunci: Deteksi dini, Pre eklamsia, Buku KIA, MAP, ROT.

\section{PENDAHULUAN}

Permasalahan

kesehatan perempuan di Indonesia saat ini adalah masih tingginya kematian ibu (AKI), walaupun dalam lima tahun terakhir angkanya terus menurun. Menurut Menteri Kesehatan (Menkes) Nila F Moelek dari 5.000 kematian per tahun, pada 2016 jumlahnya berkurang menjadi 4.912. Salah satu faktor yang mempengaruhi turunnya AKI ialah makin tingginya penggunaan fasilitas layanan kesehatan untuk proses melahirkan. Menteri kesehatan tidak memungkiri bahwa kematian ibu akibat melahirkan dipengaruhi faktor kesehatan masing-masing. Antara lain hipertensi, infeksi, anemia, termasuk kurangnya gizi. Tetapi, tambahnya, ada juga akibat faktor lain, akses transpostasi karena ibu hamil bertempat tinggal jauh dari fasilitas kesehatan. Selain itu, juga karena faktor sosial, Misalnya, masih banyak masyarakat di perdesaan yang ingin melahirkan di rumah, (Kemenkes, 2017)

Penurunan angka kematian ibu dan angka kematian bayi, salah satunya dilakukan dengan mendorong pemeriksaan kehamilan (ANC), serta pertolongan kelahiran di tenaga kesehatan terlatih. Program kesehatan ibu di Indonesia menganjurkan agar ibu hamil melakukan paling sedikit empat kali kunjungan untuk pemeriksaan selama kehamilan, yaitu paling sedikit sekali kunjungan dalam trimester pertama, minimal sekali kunjungan dalam trimester kedua, dan minimal dua kali kunjungan dalam trimester ketiga (Kemenkes, 2013).

Selama masa sebelum kehamilan dan selama kehamilan, ibu bisa mengalami masalah kesehatan. Masalah kesehatan yang timbul merupakan komplikasi kehamilan, yang akan berdampak pada kesehatan ibu dan janin selama kehamilan, dan berdampak pada kesehatan ibu dan bayi pada saat kelahiran. Hal ini nampak pada cakupan ibu hamil komplikasi yang ditangani tahun 2016 adalah 102\% yaitu pelayanan pada 4.434 ibu hamil risiko tinggi dari 4.334 perkiraan ibu hamil yang risiko tinggi. (BKKBN, 2012)

AKI di kabupaten Jombang pada tahun 2016, sebesar 80,75 per $100.000 \mathrm{KH}$. Angka tersebut berdasarkan data jumlah kematian maternal 17 kasus dari 19.477 kelahiran hidup. Cakupan K4 pada tahun 2016 sebesar 89,27\%, yaitu pelayanan pada $19.345 \mathrm{ibu}$ hamil dari 21.671 total ibu hamil. Capaian ini menurun dibanding tahun 2015 sebesar 91,4\%. Kesenjangan antara K1 dan K4 perlu dicari penyebabnya untuk dibuatkan penyelesaianya sehingga seluruh ibu hamil mendapat pelayanan paripurna. (Dinkes Kab Jombang, 2016).

Komplikasi yang terjadi selama masa kehamilan akan menyebabkan kematian pada ibu bersalin. Eklamsia merupakan penyebab terbesar kematian ibu di jawa timur yaitu 20 kasus dari 86 AKI di pada tahun 2017. Awal tahun 2018 sudah terdapat 5 kasus kematian ibu yang disebabkan karena eklamsia. (POGI, 2018) 


\section{PROFESIONAL HEALTH JOURNAL}

Volume 1, No. 2, Juni 2020 (Hal. 73-83)

Available Online at https:// https://www.ojsstikesbanyuwangi.com

Preeklamsia merupakan penyakit yang dapat dideteksi lebih awal sehingga dapat dilakukan pencegahan agar tidak terjadi komplikasi. Salah satu cara untuk mendeteksi adanya eklamsia adalah dengan melakukan deteksi dini menggunakan pengukuran tekanan darah ibu hamil secara teratur. Terjadinya preeklamsia dapat dideteksi secara dini dengan memakai Mean Arterial Pressure test (MAP) dan Roll Over Test (ROT). Kriteria minimum diagnosis preeklamsia ialah peningkatan tekanan darah yang lebih besar atau sama dengan $140 / 90 \mathrm{mmHg}$ dengan pemeriksaan $2 \mathrm{x}$ selang 6 jam dalam keadaan istirahat. (Sarwono, 2012).

Pemeriksaan ANC secara rutin yang dilakukan di pelayanan kesehatan merupakan salah satu usaha untuk mencegah terjadinya preeklamsia. Standart pemeriksaan ANC salah satunya adalah dilakukan pemeriksaan tekanan darah dan protein urine, sehingga dapat dilakukan uji kemungkinan preeklamsia (Rukiyah, 2010).

Upaya percepatan penurunan AKI dapat dilakukan dengan menjamin agar setiap ibu mampu mengakses pelayanan kesehatan ibu yang berkualitas, seperti pelayanan kesehatan ibu hamil, pertolongan persalinan oleh tenaga kesehatan terlatih di fasilitas pelayanan kesehatan, perawatan pasca persalinan bagi ibu dan bayi, perawatan khusus dan rujukan jika terjadi komplikasi, kemudahan mendapatkan cuti hamil dan melahirkan, dan pelayanan keluarga berencana. Pelayanan kesehatan ibu hamil diberikan kepada ibu hamil yang dilakukan oleh tenaga kesehatan di fasilitas pelayanan kesehatan. Proses ini dilakukan selama rentang usia kehamilan ibu yang dikelompokkan sesuai usia kehamilan menjadi trimester pertama, trimester kedua, dan trimester ketiga. (Depkes RI, 2015).

Kolifah, dkk., Pengaruh Pemanfaatan Buku KIA
Penelitian ini bertujuan untuk mengetahui Pengaruh Pemanfaatan Buku KIA Dalam Pengkajian ROT dan MAP Terhadap Deteksi Dini Pre Eklamsia Di Polindes Dukuh Arum Megaluh Jombang.

\section{METODE}

Desain penelitian analitik pendekatan Cross Sectional. Variabel bebas adalah pengukuran MAP dan ROT di buku KIA dan variable terikat adalah kejadian pre eklamsia. Populasi seluruh ibu hamil trimester III yang memiliki buku KIA di Puskesmas Jelak Ombo dengan purposive sampling di dapatkan 87 responden. Instrumen penelitian Buku KIA dan lembar pengumpul data. Data dianalisa dengan uji chi square.

\section{HASIL}

1. DATA UMUM

a. Distribusi frekuensi data umum responden di Puskesmas Jelak Ombo Jombang.

Tabel 1. Distribusi frekuensi data umum responden di Puskesmas Jelak Ombo Jombang

\begin{tabular}{lcc}
\hline \multicolumn{1}{c}{ Variabel } & f & $\%$ \\
\hline Umur tidak resiko tinggi & 67 & 77 \\
Umur resiko tinggi & 20 & 23 \\
\hline Total & 87 & 100 \\
\hline Primipara & 38 & 43,7 \\
Multipara & 48 & 55,2 \\
Grandemultipara & 1 & 1,1 \\
\hline Total & 87 & 100 \\
\hline Resiko rendah & 50 & 57,5 \\
Resiko tinggi & 24 & 27,6 \\
Resiko sangat tinggi & 13 & 14,9 \\
\hline Total & 87 & 100 \\
\hline
\end{tabular}

Hasil penelitian menunjukkan hampir seluruhnya (77\%) responden berada pada umur tidak resiko tinggi yaitu 67 responden, sebagian besar $(55,2 \%)$ responden multipara yaitu 48 responden, sebagaian besar 


\section{PROFESIONAL HEALTH JOURNAL}

Volume 1, No. 2, Juni 2020 (Hal. 73-83)

Available Online at https:// https://www.ojsstikesbanyuwangi.com

$(57,5 \%)$ responden dengan kehamilan resiko rendah yaitu 50 responden.

\section{DATA KHUSUS}

a. Distribusi responden berdasarkan deteksi dini preeklamsia dengan ROT.

Tabel 2. Distribusi responden berdasarkan deteksi dini preeklamsia dengan ROT

\begin{tabular}{lcc}
\hline $\begin{array}{l}\text { Deteksi Dini Pre } \\
\text { Eklamsia dengan }\end{array}$ & f & $\%$ \\
ROT & & \\
\hline Positif & 12 & 13,8 \\
Negatif & 75 & 86,2 \\
\hline Total & 87 & 100 \\
\hline
\end{tabular}

Hasil penelitian menunjukkan hampir seruhnya $(86,2 \%)$ responden hasil pemeriksaan ROT hasilnya negatif yaitu sebanyak 75 responden.

b. Distribusi responden berdasarkan deteksi dini preeklamsia dengan MAP.

Tabel 3. Distribusi responden berdasarkan deteksi dini preeklamsia dengan MAP

Deteksi Dini Pre

Eklamsia dengan f $\%$

MAP

\begin{tabular}{lcc}
\hline Positif & 6 & 6,9 \\
Negatif & 81 & 93,1 \\
\hline Jumlah & 87 & 100 \\
\hline
\end{tabular}

Hasil penelitian didapatkan hasil hampir seluruhnya $(93,1 \%)$ responden hasil pemeriksaan MAP hasilnya negatif yaitu sebanyak 81 responden.

c. Distribusi responden berdasarkan kejadian preeklamsia.

Kolifah, dkk., Pengaruh Pemanfaatan Buku KIA
Tabel 4. Distribusi responden berdasarkan kejadian preeklamsia

\begin{tabular}{lcc}
\hline Kejadian Pre Eklamsia & $\mathrm{f}$ & $\%$ \\
\hline Tidak Pre eklamsia & 81 & 93,1 \\
Pre eklamsia & 6 & 6,9 \\
\hline Jumlah & 87 & 100 \\
\hline
\end{tabular}

Hasil penelitian didapatkan bahwa hampir seluruhnya $(93,1 \%)$ responden persalinaan tanpa diagnose pre eklamsia yaitu sebanyak 81 responden.

d. Hubungan pemeriksaan ROT dengan kejadian pre eklamsia.

Tabel 5. Hubungan pemeriksaan ROT dengan kejadian pre eklamsia

\begin{tabular}{|c|c|c|c|c|c|c|}
\hline \multirow{3}{*}{$\begin{array}{c}\text { Hasil } \\
\text { pemerik } \\
\text { saan } \\
\text { ROT }\end{array}$} & \multicolumn{4}{|c|}{ Kejadian Pre eklamsia } & \multirow{2}{*}{\multicolumn{2}{|c|}{ Total }} \\
\hline & \multicolumn{2}{|c|}{$\begin{array}{l}\text { Tidak Pre } \\
\text { eklamsia }\end{array}$} & \multicolumn{2}{|c|}{$\begin{array}{c}\text { Pre } \\
\text { eklamsia }\end{array}$} & & \\
\hline & $\mathrm{f}$ & $\%$ & $f$ & $\%$ & $\mathrm{f}$ & $\%$ \\
\hline \multirow{2}{*}{ Negatif } & & 86 , & & & 7 & 86 , \\
\hline & 75 & 2 & 0 & 0 & 5 & 2 \\
\hline Positif & 6 & 60 & 6 & & ? & 13, \\
\hline \multirow{2}{*}{ Total } & & 93 & & & & \\
\hline & 81 & 1 & 6 & 6,9 & & 100 \\
\hline
\end{tabular}

Tabel 5 menunjukkan bahwa hampir seluruhnya (86,2\%) responden yang tidak mengalami pre eklmasia adalah responden dengan hasil pemeriksaan ROT Negatif yaitu sebanyak 75 responden dari 87 responden, sedangkan sebagian kecil $(6,9 \%)$ responden yang mengalami pre eklamsia adalah responden dengan hasil pemeriksaan ROT positif yaitu sebanyak 6 responden dari 87 responden.

Hasil uji statistic chi square menunjukkan bahwa nilai $\mathrm{p}<0,05$ maka dapat disimpulkan bahwa ada 


\section{PROFESIONAL HEALTH JOURNAL}

Volume 1, No. 2, Juni 2020 (Hal. 73-83)

Available Online at https:// https://www.ojsstikesbanyuwangi.com

hubungan antara hasil pemeriksaan ROT dengan kejadian pre eklamsia.

e. Hubungan pemeriksaan ROT dengan kejadian pre eklamsia.

Tabel 6. Hubungan pemeriksaan MAP dengan kejadian pre eklamsia

\begin{tabular}{ccccccc}
\hline Hasil & \multicolumn{3}{l}{ Kejadian Pre eklamsia } & \multirow{2}{*}{ Total } \\
\cline { 2 - 5 } $\begin{array}{c}\text { pemerik } \\
\text { saan }\end{array}$ & $\begin{array}{l}\text { Tidak Pre } \\
\text { eklamsia }\end{array}$ & \multicolumn{2}{c}{$\begin{array}{c}\text { Pre } \\
\text { eklamsia }\end{array}$} & & \\
\cline { 2 - 6 } MAP & $\mathrm{f}$ & $\%$ & $\mathrm{f}$ & $\%$ & $\mathrm{f}$ & $\%$ \\
\hline Negatif & 81 & 93,1 & 0 & 0 & 81 & 93,1 \\
Positif & 0 & 0 & 6 & 6,9 & 6 & 6,9 \\
Total & 81 & 93,1 & 6 & 6,9 & 87 & 100
\end{tabular}

$\mathrm{p}$ value $=0,000$

Tabel 6 menunjukkan bahwa hampir seluruhnya $(93,1 \%)$ responden yang tidak mengalami pre eklmasia adalah responden dengan hasil pemeriksaan MAP Negatif yaitu sebanyak 81 responden dari total 87 responden, sedangkan sebagian kecil $(6,9 \%)$ responden yang mengalami pre eklamsia adalah responden dengan hasil pemeriksaan MAP positif yaitu sebanyak 6 responden dari total 87 responden.

Hasil uji statistic chi square menunjukkan bahwa nilai $\mathrm{p}<, 05$ maka dapat disimpulkan bahwa ada hubungan antara hasil pemeriksaan MAP dengan kejadian pre eklamsia.

\section{PEMBAHASAN}

Hasil penelitian menunjukkan bahwa hampir seluruhnya (77\%) responden berada pada umur tidak beriko tinggi untuk hamil yaitu sebanyak 67 responden.

Umur ibu pada saat hamil mempengaruhi psikologis ibu dan berat badan bayi yang dilahirkan. Umur dibawah 20 tahun memiliki resiko lebih besar 2 sampai 4 kali dibandingkan ibu hamil di Kolifah, dkk., Pengaruh Pemanfaatan Buku KIA atas 20 tahun sampai 35 tahun. Ibu hamil umur 20 - 35 tahun memiliki kesiapan psikologis yang baik dan organ reproduksi dalam keadaan siap untuk proses kehamilan sehingga memiliki resiko lebih kecil (Sitorus, 2000).

Menurut Winkjosastro (2010) kematian maternal pada wanita hamil dan melahirkan pada usia di bawah 20 tahun 25 kali lebih tinggi dari pada kematian maternal yang terjadi pada usia 20-29 tahun. Kematian maternal meningkat kembali sesudah usia 30-35 tahun. Kehamilan di usia $<20$ tahun sangat berbahaya untuk kesehatan organ reproduksi yang belum kuat untuk berhubungan intim dan melahirkan, sehingga gadis diusia <20 tahun memiliki risiko 4 kali lipat mengalami luka serius dan meninggal akibat melahirkan.

Penelitian Haryani menunjukkan bahwa terdapat hubungan yang bermakna antara usia ibu hamil berisiko dengan kejadian Preeklampsia/eklampsia. Perhitungan Relative Risk sebesar 2,146 dan lebih besar dari 1 menunjukkan bahwa kelompok usia $<20$ tahun dan >35 tahun lebih beresiko mengalami preeklampsia/ eklampsia dari pada kelompok usia 20-35 tahun.

Skor puji rochyati menunjukkan bahwa umur ibu dibawah 16 tahun pada saat hamil pertama memiliki skor 4 , begitu juga ibu yang terlalu tua hamil yaitu umur lebih dari 35 tahun juga memiliki skor 4, sehingga ibu masuk dalam kelompok kehamilan resiko tinggi. Ibu hamil dengan usia lebih dari 35 tahun memiliki resiko terjadi pre eklamsia. Penambahan usia menyebabkan kemampuan organ reproduksi menurun dan jaringan serta otot otot organ reproduksi tidak lentur sehingga meningkatkan aliran tekanan darah sehingga memicu terjadinya preeklamsia (Rochayati, 2003).

Usia yang paling aman untuk hamil dan melahirkan adalah $20-30$ tahun 


\section{PROFESIONAL HEALTH JOURNAL}

Volume 1, No. 2, Juni 2020 (Hal. 73-83)

Available Online at https:// https://www.ojsstikesbanyuwangi.com

dimana secara fisiologis organ organ reproduksi wanita sudah matang untuk menjalankan fungsinya sehingga kehamilan bisa berjalan dengan normal. Keadaan kehamilan yang fisiologis akan mempengaruhi keadaan janin dalam kandungan ibu sehingga janin dapat tumbuh normal dan lahir menjadi bayi yang sehat. Psikologis ibu yang hamil pada usia matang 20-30 tahun sudah dalam tahap matang dan siap menghadapi perubahan peran sebagai seorang ibu, sehingga dapat menjalani masa nifas dengan baik.

Hasil penelitian menunjukkan bahwa rata rata responden merupakan multigravida dengan kehamilan ke dua. Hasil penelitian menunjukkan lebih dari setengah $(55,2 \%)$ responden multigravida, dengan kehamilan tertinggi yaitu kehamilan ke 6.

Penelitian Asmana (2016)

mengatakan bahawa tidak terdapat hubungan antara paritas dengan preeklampsia. Paritas 0 belum dapat ditentukan apakah merupakan faktor risiko atau faktor protektif.

Kejadian preeklamsia pada primigravida memiliki frekuensi lebih tinggi dibandingkan dengan pada multigravida. Kehamilan pertama kali akan merangsang terbentuknya "blocing antibodies" terhadap antigen tidak sempurna. Hal ini merupakan reaksi penolakan hasil konsepsi oleh ibu sendiri sehingga terjadi reaksi intoleransi ibu terhadap placenta, hal inilah yang memicu terjadinya pre eklamsia (Sudhaberata, 2008).

Proses kehamilan tentunya disertai dengan perubahan fisiologis dan psikologis, agar dapat menjalani kehamilan dengan baik, maka ibu harus beradaptasi terhadap perubahan tersebut. Ibu primigravida memerlukan waktu untuk bisa beradaptasi dengan baik, jika ibu belum mampu beradaptasi maka akan Kolifah, dkk., Pengaruh Pemanfaatan Buku KIA timbul berbagai ketidaknyaman yang dikeluhkan oleh ibu hamil. Ketidaknyaman yang dirasakan oleh ibu pada awal kehamilan antara lain mual, muntah, pusing dan lemah, jika hal ini tidak diberikan asuhan yang tepat maka akan memberikan dampak yang tidak baik pada ibu dan janin. Salah satunya adalah terjadinya preeklamsia.

Hasil penelitian menunjukkan bahwa sebagain besar responden $(57,5 \%)$ kelompok resiko kehamilan rendah dengan skor 2, yaitu sejumlah 50 responden.

KRST merupakan kelompok risiko ibu hamil yang jumlahnya paling banyak pada kasus kematian maternal diikuti oleh KRT dan KRR paling sedikit. Hal tersebut merupakan sesuatu yang wajar, karena meninggal merupakan kondisi yang selalu didahului oleh keadaan penyakit yang sangat berat dengan faktor risiko yang sangat tinggi. Namun masih didapatkan kehamilan dengan risiko rendah, hal ini membuktikan bahwa tidak ada kehamilan yang tidak berisiko. Sesuai dengan sistem skor pada KSPR, bahwa 2 merupakan skor minimal pada setiap kehamilan (Prawirohardjo, 2010).

Menurut beberapa ahli menyatakan bahwa seorang ibu hamil dapat mempunyai faktor risiko tunggal, ganda dua, tiga ataupun lebih yang tampak dalam perhitungan jumlah skor dan dengan pengaruh risiko sinergistik dan kumulatif terjadinya komplikasi yang lebih berat (Ummah, 2015).

Hasil penelitian Hidayah 2018, Hubungan Tingkat Risiko Kehamilan dengan Kejadian Komplikasi Persalinan di RSUD Panembahan Senopati Bantul menunjukkan bahwa terdapat hubungan yang signifikan antara tingkat risiko kehamilan kehamilan resiko sangat tinggi (KRST) dan kehamilan resiko rendah (KRR) dengan kejadian komplikasi persalinan. Ratio prevalence (RP) 4,4 yang artinya ibu dengan tingkat risiko KRST 4,4 


\section{PROFESIONAL HEALTH JOURNAL}

Volume 1, No. 2, Juni 2020 (Hal. 73-83)

Available Online at https:// https://www.ojsstikesbanyuwangi.com

kali lebih berisiko terjadi komplikasi persalinan dibandingkan dengan ibu tingkat risiko KRR.

Ibu hamil dengan kelompok resiko rendah bukan berarti tidak memiliki potensi untuk menjadi patologi, semua ibu hamil memiliki peluang untuk menjadi patologis, sehingga perlu dilakukan pemantauan secara terpadu dan berkesinambungan sehingga ibu dapat menjadi melahirkan secara fisiologis.

Hasil penelitian menunjukkan bahwa hampir seluruhnya $(86,2 \%)$ sejumlah 75 ibu hamil yang dilakukan pengukuran ROT memiliki hasil negative.

Roll Over Test (ROT) adalah pengukuran tekanan darah pada dua posisi yang berbeda, yaitu pada posisi tidur sisi kiri dan posisi tidur terlentang. ROT dikatakan positif jika terjadi perubahan/peningkatan tekanan darah diastolik antara posisi tidur samping dan terlentang $\geq 15 \mathrm{mmHg}$ dan negatif saat perubahan diastol $<15 \mathrm{mmHg}$ (Suprihatin and Norontoko, 2016).

Selama masa kehamilan akan terjadi perubahan fisiologis dan psikologis. Perubahan fisiologis antara lain perubahan pada system hematologi. Perubahan pada system hematologi memberikan efek pada tekanan darah jika pengukurannya pada posisi yang berbeda. Pada posisi terlentang tekanan dari Vena Cava Inferior (VCI) menyebabkan penurunan aliran balik Vena ke jantung dan mengakibatkan volume stroke dan kardiac output menurun. Berbalik dari lateral ke posisi terlentang dapat mengakibatkan penurunan curah jantung sebesar 25\%, sehingga menyebabkan terganggunya aliran darah uteroplasenta (Sherwood, 2014).

Penelitian Sembiring (2018) nilai

ROT secara signifikan berbeda pada kelompok normal tensi dengan kelompok hipertensi pada kehamilan. Perbedaan ini juga memiliki hubungan positif yang sangat kuat terhadap Kolifah, dkk., Pengaruh Pemanfaatan Buku KIA hipertensi pada kehamilan. Ibu hamil dengan ROT positif berisiko 20 kali lipat untuk mengalami hipertensi pada usia kehamilan 27 minggu dibandingkan dengan kelompok ROT negatif. Pada usia kehamilan 32 minggu risiko terjadinya hipertensi meningkat pada ibu hamil dengan ROT K1 positif sebesar 2 kali, ROT K2 positif sebesar 2 kali dan risiko terbesar apabila ROT pada saat usia kehamilan 32 minggu positif sebesar 98 kali dibandingkan ibu hamil dengan ROT negatif.

Responden dengan hasil ROT positif memiliki peluang terjadinya pre eklamsia kehamilan, sehingga perlu dilakukan pengawasan yang berkesinambungan agar tidak terjadi komplikasi pada ibu dan janinnya.

Hasil penelitian menunjukkan bahwa hampir seluruhnya $(93,1 \%)$ sejumlah 81 ibu hamil yang dilakukan pengukuran MAP memiliki hasil negative.

Mean Arterial Pressure (MAP) adalah nilai rata-rata tekanan arteri yang dinilai dengan mengukur tekanan diastole dan sistol, kemudian menentukan nilai rata-rata arteri. MAP dikatakan positif jika hasilnya $>90 \mathrm{mmHg}$, negatif jika hasilnya $<90 \mathrm{mmHg}$. MAP dikatakan positif jika hasilnya $>90 \mathrm{mmHg}$ dan negatif jika hasilnya $<90 \mathrm{mmHg}$ (Suprihatin and Norontoko, 2016).

Hasil penelitian Sembiring (2016), menunjukkan bahwa MAP positif ( $>90$ $\mathrm{mmHg}$ ) secara signifikan berbeda pada kelompok normal tensi dengan kelompok hipertensi pada usia kehamilan 27 minggu dan 32 minggu. Peluang ibu hamil dengan MAP positif untuk menderita hipertensi pada usia kehamilan 27 minggu sebanyak 3,381 kali (95\% CI : 2,361 - 4,841) dibandingkan dengan MAP negatif.

Ibu hamil fisiologis mengalami peningkatan volume darah sebesar $50 \%$ sampai usia 34 minggu di ikuti dengan 


\section{PROFESIONAL HEALTH JOURNAL}

Volume 1, No. 2, Juni 2020 (Hal. 73-83)

Available Online at https:// https://www.ojsstikesbanyuwangi.com

peningkatan curah jantung sebesar 40\%, hal ini untuk mencegah terjadinya resistensi vaskular sistemik dikarenakan peningkatan vasodilatasi perifer sebesar 25 $-30 \%$ (Patricia, et al., 2016).

Ibu hamil tidak semua mampu beradaptasi terhadap perubahan fisiologis yang dialaminya. Hal ini yang menyebabkan perubahan fisiologis menjadi patologis. Ibu hamil yang tidak dapat beradaptasi terhadap perubahan system kardiovaskular secara fisiologis akan menyebabkan ketidakseimbangan antara volume darah dan curah jantung terhadap vasodilatasi perifer yang terjadi, sehingga akan menyebabkan terganggunya gaya darah terhadap dinding pembuluh darah dan pada akhirnya nilai MAP meningkat, diikuti dengan meningkatnya tekanan darah.

MAP paling prediktif untuk menjadi parameter jika pemeriksaan dilakukan pada trimester kedua kehamilan. Ini disebabkan karena pada trimester pertama, tekanan darah sistolik dan diastolik mengalami peningkatan yang fisiologis sehingga menunjukkan akurasi yang buruk sebagai prediktor preeclampsia (Daiv and Sawant, 2014).

Hasil penelitian menunjukkan bahwa hampir setengahnya responden $(49,4 \%)$ memiliki IMT lebih yaitu sejumlah 43 responden.

Penelitian Reslan and Khalil (2010) meunjukkan bahwa wanita obesitas mempunyai risiko mengalami preeklampsia/eklampsia 3,5 kali lebih tinggi dibandingkan dengan wanita dengan IMT normal. Wanita hamil dengan IMT obesitas berisiko 5 kali lebih besar untuk menderita preeklampsia dibandingkan dengan wanita hamil dengan IMT normal.

Obesitas meningkatkan risiko pre eklamsia sebanyak 2,47 kali lipat (95\% CI, 1,66 - 3,67), sedangkan wanita dengan IMT sebelum hamil > 35 dibandingkan

Kolifah, dkk., Pengaruh Pemanfaatan Buku KIA dengan IMT 19 - 27 memiliki risiko preeklampsia 4 kali lipat (POGI, 2018).

Hasil penelitian menunjukkan bahwa hampir seluruhnya $(93,1 \%)$ responden tidak mengalami pre eklamsia. sebagain kecil $(6,9 \%)$ responden yang mengalami pre eklmasia.

Hal ini sesuai dengan hasil deteksi dini pre eklamsia dengan pengukuran ROT dan MAP.

Hasil penelitian menunjukkan bahwa ada hubungan yang signifikan $\mathrm{p}<0,005$ antara deteksi dini menggunakan pengukuran ROT dengan kejadian pre eklamsia. Responden yang hasil pemeriksaan ROT positif pada saat proses persalinan mengalami pre eklamsia.

Hasil penelitian menunjukkan bahwa ada hubungan yang signifikan antara deteksi dini menggunakan pengukuran MAP dengan kejadian pre eklamsia. Responden yang hasil pemeriksaan MAP positif pada saat proses persalinan mengalami pre eklamsia.

Ibu hamil yang terdeteksi pre eklamsia dengan pengukuran ROT dan MAP perlu dilakukan pengawasan yang berkesinambungan sampai dengan proses persalinan. Persalinan harus dilaksanakan di RS dengan fasilitas Sectio Secarea. Konseling dan penjelasan pada ibu hamil harus diberikan sejak awal terdeteksi pre eklamsia, sehingga dapat mencegah terjadinya komplikasi pre eklamsia baik pada ibu maupun pada janin.

Buku KIA merupakan buku yang sangat penting bagi ibu hamil, karena di dalam buku KIA terekam kondisi ibu selama hamil sehingga didapatkan informasi tentang keadaan kehamilan ibu hamil. Buku KIA memberikan gambaran tentang kondisi ibu setiap kali kunjungan, di dalam buku KIA juga dapat di lakukan deteksi dini terjadinya eklmasia dan pre eklamsia melalui tekanan darah dan berat badan ibu hamil. Hasil pengukuran tekanan darah dapat diketahui ROT dan MAP yang 


\section{PROFESIONAL HEALTH JOURNAL}

Volume 1, No. 2, Juni 2020 (Hal. 73-83) Available Online at https:// https://www.ojsstikesbanyuwangi.com

merupakan salah satu indicator terjadinya pre eklamsia. Buku KIA sangat efektif dalam melakukan deteksi dini pre eklamsia.

\section{KESIMPULAN DAN SARAN}

a. Ada hubungan antara pengkuran ROT dengan kejadian pre eklamsia

b. Ada hubungan antara pengukuran MAP dengan kejadian pre eklamsia

c. Buku KIA sangat efektif dalam melakukan deteksi dini pre eklamsia

Penelitian ini menunjukkan efektifitas buku KIA dalam pemanfaatnnya untuk deteksi dini pre eklamsia melalui pengukuran ROT dan MAP. Pengukuran ROT dan MAP perlu dilakukan di setiap trimester terutama trimester III sehingga bisa dilakukan tindakan penatalaksanaan lebih awal jika terjadi pre eklamsia. Pemeriksaan ANC terpadu merukanan kegiatan yang sangat menunjang dalam pemanfaatn buku KIA, kerena dalam melakukan pemeriksaan ANC semua di dokumentasikan dalam buku KIA. Hasil penelitian mengharapkan semua pelayanan kesehatan yang melayani pemeriksaan kehamilan wajib memanfaatkan buku KIA, sehingga kesehatan ibu dan janin dapat dipantau secara berkesinambungan.

\section{DAFTAR PUSTAKA}

Awatiful Azza. (2018) Roll Over Test Sebagai Pprediksi Pre Eklamsia pada Ibu Hamil

http://jurnal.unmuhjember.ac.id/index. $\mathrm{php} / \mathrm{psn} /$ article/download/1751/1438

Asmana, Siqbal Karta dan Syahredi, Noza Hilbertina. (2016) Hubungan antara usia dan paritas dengan kejadian preeklampsia berat di Rumah Sakit Achmad Mochtar Bukittinggi 2012 2013. Jurnal Kesehatan Andalas. 2016; 5(3) http://jurnal.fk.unand.ac.id/
Badan Kependudukan dan Keluarga Berencana Nasional. (2012). Survei demografi dan kesehatan Indonesia. Jakarta

Dinas Kesehatan Jombang. (2014). Profil Kesehatan Jombang.

Dinas Kesehatan Jawa Timur. (2013). Profil Kesehatan Jawa Timur.

Daiv, G. R. and Sawant, V. (2014). Mean Arterial Blood Pressure For Early Prediction In Pre Eclampsia. Online International Interdisciplinary Research Journal. 4(5). pp. 106-116. Available at: http://www.oiirj.org/oiirj/septoct2014/14.pdf.

Ghojazadeh, M. et al. (2013). Prognostic Risk Factors For Early Diagnosing Of Preeclampsia In Nulliparas. Nigerian medical journal : journal of the Nigeria Medical Association. 54(5). pp. 344-8. doi: 10.4103/0300-1652.122368

Hidayah, prima, Heni Puji Wahyuningsih , dan Kusminatun, (2018). Hubungan Tingkat Risiko Kehamilan dengan Kejadian Komplikasi Persalinan di RSUD Panembahan Senopati Bantul. Jurnal Kesehatan Vokasional. Vol. 3 No 1 - Mei 2018 ISSN 2541-0644 (Print) ISSN 2599-3275 (Online) Dapat di akses di http://journal.ugm.ac.id/jkesvo

Haryani, Ayu Putri, dan Moch Maroef, Sri Adilla. (2015). Hubungan Usia Ibu Hamil Berisiko dengan Kejadian Preeklampsia/Eklampsia di RSU Haji Surabaya Periode 01 Januari 2013-31 Desember 2013. http://ejournal.umm.ac.id/index.php/sai $\underline{\text { nmed/article/view/4192 }}$ 


\section{PROFESIONAL HEALTH JOURNAL}

Volume 1, No. 2, Juni 2020 (Hal. 73-83)

Available Online at https:// https://www.ojsstikesbanyuwangi.com

Kementerian Kesehatan RI. Profil Kesehatan Indonesia 2012. Jakarta: Kementerian Kesehatan RI. 2013. https://www.kemkes.go.id/

Kementerian Kesehatan RI. Profil kesehatan Indonesia 2016. Jakarta: Kementerian Kesehatan RI. 2017. https://www.kemkes.go.id/

Kaytri, S. (2016). Role Of Uterine Artery Doppler And Roll Over Test In Prediction Of Pregnancy Induced Hypertension. International Journal of Reproduction, Contraception, Obstetrics and Gynecology. 5(10). pp. 3556-3559. Comparison between rollover test and placental localization for early prediction of preeclampsia https://www.researchgate.net/publicati on/282833776_Comparison_between_r ollover_test_and_placental_localizatio n_for_early_prediction_of_preeclampsi a

Patricia, K. et al. (2016). Association Between Hypertension And Quality of Life In Pregnancy. Hypertension in pregnancy. 1955 (March). pp. 1 -9. doi: 10.3109/10641955.2016.1143485. https://www.ncbi.nlm.nih.gov/pubmed/ $\underline{26930125}$

POGI. (2016) Buku Panduan Klinis Obstetri Ginekologi. POGI Surabaya 2016.

https://www.researchgate.net/publicati on/326694737_Buku_Panduan_Klinis_ Obstetri_Ginekologi_-

_POGI_Surabaya_2016

Prawirohardjo, Sarwono. (2010). Buku Acuan Nasional Pelayanan Kesehatan Maternal dan Neonatal. Jakarta : PT Bina Pustaka Sarwono Prawirohardjo.
Prawirohardjo, Sarwono. 2010. Ilmu Kebidanan. Jakarta: Yayasan Bina Pustaka Sarwono Prawirohardjo.

Rukiyah \& Yulianti. (2010). Asuhan Kebidanan IV (Patologi Kebidanan). Jakarta: Info Media.

Rochjati P. (2003). Skrining Antenatal Pada Ibu Hamil: Pengenalan Faktor Risiko. Surabaya: Airlangga University Press

Reslan, O. M. and Khalil, R. A. (2010). Molecular And Vascular Targets In The Pathogenesis And Management Of The Hypertension Associated With Preeclampsia. Cardiovascular \& hematological agents in medicinal chemistry. 8(4), pp. 204-26. doi: $10.2174 / 187152510792481234$.

https://www.ncbi.nlm.nih.gov/pubmed/ $\underline{20923405}$

Sitorus., (2000). Diagnosis dan Penatalaksanaan Preeklampsia Eklampsia, in : Holistic and Comprehensive Management Eclampsia. Surakarta.

Sudhaberata Ketut, (2008). Penanganan Preeklampsia Berat dan Eklampsia, UPF. Ilmu Kebidanan dan Penyakit Kandungan, Rumah Sakit Umum Tarakan Kalimantan Timur. https://studylibid.com/doc/336751/sud haberata-ketut--2008--penangananpreeklampsia-berat-dan

Suprihatin, E. and Norontoko, D. A. (2016). Prediction of Preeclampsia by a Combination of Body Mass Index (BMI), Mean Arterial Pressure (MAP), and Roll Over Test (ROT). http://eprints.ners.unair.ac.id/321/ 


\section{PROFESIONAL HEALTH JOURNAL}

Volume 1, No. 2, Juni 2020 (Hal. 73-83)

Available Online at https:// https://www.ojsstikesbanyuwangi.com

Sherwood, L. (2014). Fisiologi Manusia Dari Sel ke Sistem. Edisi 8. Edited by B. U. Pendit et al. Jakarta: EGC

Sembiring, Rumelia Lubina. (2018). Aktivitas fisik, Stress, Mean Arterial Pressure (MAP), Roll Over Test (ROT) dan Hormon Kortisol sebagai Predictor Hipertensi dalam Kehamilan. http://digilib.unhas.ac.id/uploaded files /temporary/DigitalCollection/OWM1Zj FlNjg1NmNiZWQ1Y2M3ZWI4ZTgW $\underline{\text { M2I1NjUwNDMzOWIzMDY5ZQ==. }}$ pdf

Ummah, Faizatul. Kontribusi Faktor Risiko I Terhadap Komplikasi
Kehamilan Di Rumah Sakit Muhammadiya Surabaya. Volume 07, No.01, April 2015. http://jurnal.stikesmuhla.ac.id/wpcontent/uploads/2016/12/01-08-jurnalapril-2015-Faiz.pdf

WHO, et al. (2015). Trends In Maternal Mortality: 1990 to 2015. Executive Summary. WHO Library Cataloguing. p. 14. doi: 10 .

Wiknjosastro H. (2009). Ilmu Kebidanan. Edisi ke-4 Cetakan ke-2. Jakarta: Yayaan Bina. Pustaka Sarwono Prawirohardjo 